\title{
CAPILLARY BLOOD PRESSURE IN MAN. DIRECT MEASUREMENTS IN THE DIGITS DURING INDUCED VASOCONSTRICTION ${ }^{1}$
}

\author{
By LUDWIG W. EICHNA AND ROBERT W. WILKINS \\ (From the Department of Medicine, The Johns Hopkins University School of Medicine, \\ Baltimore)
}

(Received for publication June 1, 1942)

The present studies were undertaken because it was believed that direct measurements of capillary blood pressure in normal and hypertensive subjects might yield information concerning the nature of the peripheral resistance to blood flow in patients with hypertension. In man, only the capillaries of the digital nail-folds have been readily accessible for direct measurement of capillary blood pressure; but, digital circulation is very labile and readily affected by numerous influences $(1,2)$. Therefore, before proceeding to comparisons of digital capillary blood pressure in different individuals, it seemed necessary to know the extent to which such pressures are altered by those physiologic influences known to affect the digital circulation. This communication deals with the effects of one of these influences, namely, digital vasoconstriction.

\section{METHODS}

The methods will be considered under two headings: (1) General and (2) Particular. The general methods were employed uniformly in all of these studies of capillary blood pressure. The methods designated particular pertain only to the experiments of this publication.

\section{General}

The direct micro-injection method (Landis) (3), modified as previously described (4), was used to measure the capillary blood pressure in single capillaries in the nail folds of the fingers. The glass micropipette and the connecting manometer system were filled either with Ringer's solution or with 0.85 per cent sodium chloride solution, each containing heparin (3 mgm. per $100 \mathrm{cc}$.), and adjusted to a final $\mathrm{pH}$ between 7.3 and 7.4. Bubbles were carefully eliminated. The micropipette (orifice $6 \mu$ to $10 \mu$ in diameter) was inserted into the capillary in such a manner that the blood flow within the capillary was not visibly altered. When alteration of capillary blood flow occurred and persisted, observations were discontinued. Only measurements obtained while the blood

\footnotetext{
1 Supported by a grant from The Commonwealth Fund for the study of essential hypertension.
}

flow in the capillary remained visibly normal were recorded as capillary blood pressures. The pressure reading was made when equilibrium had been established between the pressure within the capillary and that within the micropipette. Equilibrium was indicated by the pulsatile oscillation of erythrocytes in the extreme tip of the micropipette but without progressive movement either into or out of the micropipette. A free communication between the lumina of micropipette and capillary was insured at all times, by repeatedly testing the rapidity with which the erythrocytes moved into or out of the tip of the micropipette when the pressure within the micropipette was altered from the equilibrium level by not more than 1 to $2 \mathrm{~mm}$. $\mathrm{Hg}$.

Approximately 1 hour before measurements of capillary blood pressure were begun, the most superficial, nonliving, layer of the epidermis covering the nail fold was cut away with a keen razor blade. If viable tissue was cut and bleeding ensued, observations were not made on that nail fold.

All subjects lay supine, with the head elevated $10^{\circ}$ to $15^{\circ}$. The nail fold was placed at a level approximating that of the right auricle, i.e., 3 to $6 \mathrm{~cm}$. posterior to the angle of Louis. In no subject was there an increase in systemic venous pressure, as judged by distension of the superficial veins. Except when purposely altered, the observations were made in a warm room $\left(23^{\circ}\right.$ C. to $28^{\circ}$ C.). The temperature of the body was measured usually by a mouth-thermometer, occasionally by an indwelling rectal thermocouple. Digital skin temperature was determined at frequent intervals by means of copperconstantan thermocuples, constantly in contact with the pads of the digits. The digital skin temperature was not uniform in all subjects, but throughout a single experiment it remained fairly constant. In most observations, it was between $30^{\circ} \mathrm{C}$. and $33^{\circ} \mathrm{C}$., a state hereafter referred to as moderate digital vasodilatation.

Brachial arterial pressure was determined by the usual auscultatory method (mercury manometer) at the beginning and end of each experiment, and often more frequently. These measurements were made in the extremity in which capillary blood pressure was determined. After each measurement of arterial pressure, sufficient time was allowed for recovery from reactive hyperemia before capillary blood pressure determinations were resumed. For the sake of convenience, "mean" arterial pressure was assumed to be one-half of the sum of the systolic and diastolic pressures.

Reflex vasodilatation was produced by warming the body of the subject until sweating was profuse and the 
temperature of the exposed digits reached $33^{\circ} \mathrm{C}$. to $35^{\circ}$ C. In these experiments, the temperature of the room was maintained at about $20^{\circ} \mathrm{C}$.

When histamine was employed to produce local vasodilatation, histamine acid phosphate (diluted 1:100 with 0.85 per cent salt solution) was pricked into the dorsum of the finger in three sites, each $0.5 \mathrm{~cm}$. proximal to the nail-fold. Capillary blood pressure was measured when the resulting local erythema was pronounced, usually 5 to 12 minutes (and never later than 24 minutes) after pricking in the histamine.

Reactive hyperemia of the digit was produced by releasing the digital circulation after it had been completely arrested for either 5 or 10 minutes. The circulatory arrest was obtained by inflating, to pressures well above the systolic arterial pressure, a pneumatic cuff, encircling either the forearm or the base of the digit. The capillary blood pressure was determined as quickly as possible after the release of the circulation: within 30 to 40 seconds after a 5 minute period of ischemia; within 60 seconds after a 10 minute period of ischemia.

Interruption of the sympathetic innervation of the digits was accomplished either (a) temporarily, by the injection of 2 per cent procaine into the region of the stellate and upper thoracic sympathetic ganglia, or (b) permanently, by preganglionic sympathectomy of the upper extremity by the method of Smithwick $(5,6)$. The adequacy of the sympathetic denervations was confirmed by the absence of vasoconstrictions of the neurogenic type in response to stimuli which induced vasoconstrictions in a normally innervated digit of the same subject. At least 7 to 10 days elapsed between operative sympathectomy and determination of capillary blood pressure in the sympathectomized digits.

\section{Particular}

The determinations of capillary blood pressure before, during, and after vasoconstriction were made while the micropipette was constantly in the same location in a given capillary. One observer continously adjusted the pressure in the micropipette, keeping it always in equilibrium with the pressure in the capillary. Whenever equilibrium points were established ( 5 to 15 second intervals), this observer signaled an assistant, who read the pressure in the manometer system connected with the micropipette. During such a series of readings, a third observer administered vasoconstrictor stimuli. Often, the nature of the stimulus and the time of its application were unknown to the observer adjusting the pressure in the micropipette.

Vasoconstrictions in the digits, i.e., reductions in digital volume (and presumably in blood flow), were induced by the following stimuli: touching the skin of a remote area (e.g., face, shoulder, or leg) with ice, or pricking it with a sharp object, having the subject take a deep breath, or solve mentally a problem in arithmetic. Vasoconstrictions caused by such stimuli are known to be mediated over sympathetic nervous pathways (7), and are here termed neurogenic. Digital vasoconstrictions were also induced by the intravenous injection of epinephrin hydrochloride in doses of 1 to 2.5 gamma ( 0.1 to 0.25 cc. of a $1: 100,000$ solution).

Changes in digital volume during vasoconstrictions were recorded optically by the plethysmographic method of Bolton, Carmichael, and Stürup (8). Plethysmographs were applied usually to 2 digits : (1) a finger, usually the thumb, of the hand in which capillary blood pressure was being determined; (2) that finger of the opposite hand, corresponding to the one serving for measurements of capillary blood pressure. Occasionally, the great toe of one foot was substituted for one of the fingers.

Most of the subjects were young adults. One group comprised normal and hypertensive subjects whose capillaries were of normal size. With normal capillaries, it was technically difficult to record continuously the capillary blood pressure for sufficiently long periods of time. Many additional observations were, therefore, made in a group of patients having Raynaud's disease or scleroderma. Their abnormally large capillaries presented fewer technical difficulties. Only in the latter subjects was capillary blood pressure correlated with simultaneous graphic recording of digital vasoconstrictions.

\section{RESULTS}

\section{A. Subjects with capillaries of normal size}

In 3 normal and 4 hypertensive subjects, the capillary blood pressure was determined before and during stimuli known to induce neurogenic vasoconstrictions (Table I). After the administration of each stimulus, there occurred a temporary fall in the capillary blood pressure, followed by a return to the initial level. At times, the capillary blood pressure measured 5 to 10 seconds after the application of the stimulus was not altered from the initial level; but the second reading, 10 to 15 seconds after the stimulus, was invariably lowered. The duration (10 to 55 seconds) and magnitude ( 2 to $10 \mathrm{~mm}$. $\mathrm{Hg}, 5$ to 33 per cent) of these falls in capillary blood pressure were approximately equal in both normal and hypertensive subjects (Table I).

In 2 subjects, one normal, the other hypertensive, the observations were made during reflex vasodilatation. In each subject, decreases in capillary blood pressure followed the administration of the stimulus; in fact, the greatest falls $(8 \mathrm{~mm} . \mathrm{Hg}$ and $10 \mathrm{~mm} . \mathrm{Hg}$ ) occurred in these subjects ( $\mathrm{Ta}$ ble I). 
TABLE I

Change in capillary blood pressure following " neurogenic" vasoconstrictor stimuli. Normal sized capillaries. Intact innervation

\begin{tabular}{|c|c|c|c|c|c|c|c|c|}
\hline \multirow{2}{*}{$\begin{array}{c}\text { Subject } \\
\text { (Sex, age) }\end{array}$} & \multirow{2}{*}{$\begin{array}{l}\text { Arterial } \\
\text { pressure }\end{array}$} & \multirow{2}{*}{$\begin{array}{l}\text { Skin } \\
\text { tem- } \\
\text { pera- } \\
\text { ture }\end{array}$} & \multirow{2}{*}{$\begin{array}{l}\text { Location in } \\
\text { capillary where } \\
\text { pressure was } \\
\text { measured }\end{array}$} & \multicolumn{2}{|c|}{ Capillary blood pressure } & \multirow{2}{*}{$\begin{array}{l}\text { Dura- } \\
\text { tion of } \\
\text { change } \\
\text { in cap- } \\
\text { illary } \\
\text { blood } \\
\text { pres- } \\
\text { sure }\end{array}$} & \multirow{2}{*}{ Stimulus } & \multirow{2}{*}{ Remarks } \\
\hline & & & & Initial & $\begin{array}{l}\text { Maximum } \\
\text { change due to } \\
\text { stimulus }\end{array}$ & & & \\
\hline
\end{tabular}

NORMAL SUBJECTS

\begin{tabular}{|c|c|c|c|c|c|c|c|c|c|}
\hline (F, 38) & $\begin{array}{c}\text { mm. } \text { Hg } \\
148 / 94 \\
148 / 94 \\
148 / 94\end{array}$ & $\begin{array}{l}{ }^{\circ} C . \\
31.6 \\
31.6 \\
31.6\end{array}$ & $\begin{array}{l}\text { Venous } \operatorname{limb} \\
\text { Venous } \operatorname{limb} \\
\text { Venous } \operatorname{limb}\end{array}$ & $\begin{array}{c}m m . H_{8} \\
20.5 \\
22.0 \\
20.5\end{array}$ & $\begin{array}{c}m m . H_{g} \\
-3.5 \\
-3.0 \\
-2.5\end{array}$ & $\begin{array}{c}\text { Per cent } \\
\text { of } \\
\text { initial } \\
-17.1 \\
-13.6 \\
-12.2\end{array}$ & $\begin{array}{l}\text { seconds } \\
15 \\
40 \\
15\end{array}$ & $\begin{array}{l}\text { Deep breath } \\
\text { Deep breath } \\
\text { Pin prick }\end{array}$ & \\
\hline $\begin{array}{l}\text { R. H. } \\
(\mathbf{M}, \mathbf{2 6})\end{array}$ & $124 / 68$ & 33.5 & Arteriolar limb & 31.5 & -8.5 & -27.0 & 45 & Deep breath & Reflex vasodilatation \\
\hline$\underset{(F, 32)}{\text { M. E. }}$ & $116 / 76$ & 32.3 & Summit & 29.0 & -6.0 & -20.7 & 55 & $\begin{array}{l}\text { Instructions } \\
\text { before deep } \\
\text { breath }\end{array}$ & \\
\hline \multicolumn{4}{|c|}{ Average-Normals } & & -4.7 & -18.1 & 34 & & \\
\hline
\end{tabular}

HYPERTENSIVE SUBJECTS

\begin{tabular}{|c|c|c|c|c|c|c|c|c|c|}
\hline$\underset{(M, 41)}{J} \cdot \mathbf{A}$. & $148 / 106$ & 31.4 & Venous limb & 20.0 & -5.5 & -27.5 & 45 & Deep breath & \\
\hline $\begin{array}{l}\text { C. } . \text { B. } \\
(\mathbf{M}, 35)\end{array}$ & $222 / 148$ & 35.5 & Arteriolar limb & 57.0 & -5.0 & -8.8 & 50 & Pin prick & \\
\hline $\begin{array}{l}\text { E. B. } \\
(\mathbf{F}, 35)\end{array}$ & $\begin{array}{l}232 / 172 \\
232 / 172 \\
218 / 154 \\
220 / 160\end{array}$ & $\begin{array}{l}33.0 \\
33.2 \\
33.2 \\
33.4\end{array}$ & $\begin{array}{l}\text { Venous limb } \\
\text { Summit } \\
\text { Arteriolar limb } \\
\text { Arteriolar limb }\end{array}$ & $\begin{array}{l}20.0 \\
40.0 \\
28.0 \\
30.0\end{array}$ & $\begin{array}{r}-6.0 \\
-2.0 \\
-8.0 \\
-10.0\end{array}$ & $\begin{array}{l}-30.0 \\
-5.0 \\
-28.6 \\
-33.3\end{array}$ & $\begin{array}{c}30 \\
? \\
15 \\
10+\end{array}$ & $\begin{array}{l}\text { Deep breath } \\
\text { Deep breath } \\
\text { Pin prick } \\
\text { Deep breath }\end{array}$ & $\begin{array}{l}24 \text { minutes after intradermal } \\
\text { histamine }(1: 100) \\
\text { Reflex vasodilatation } \\
\text { Reflex vasodilatation }\end{array}$ \\
\hline $\begin{array}{l}\text { H. B. } \\
(\mathbf{M}, 35)\end{array}$ & $\begin{array}{l}178 / 136 \\
178 / 136\end{array}$ & $\begin{array}{l}33.6 \\
33.6\end{array}$ & $\begin{array}{l}\text { Venous limb } \\
\text { Venous limb }\end{array}$ & $\begin{array}{l}22.0 \\
21.0\end{array}$ & $\begin{array}{l}-5.0 \\
-5.0\end{array}$ & $\begin{array}{l}-22.7 \\
-23.8\end{array}$ & $\begin{array}{l}15 \\
15\end{array}$ & $\begin{array}{l}\text { Deep breath } \\
\text { Deep breath }\end{array}$ & $\begin{array}{l}16 \text { minutes after intradermal } \\
\text { histamine }(1: 100) \\
20 \text { minutes after intradermal } \\
\text { histamine }(1: 100)\end{array}$ \\
\hline \multicolumn{4}{|c|}{$\begin{array}{l}\text { Average-Hypertensives } \\
\text { Average of all }\end{array}$} & & $\begin{array}{l}-5.8 \\
-5.4\end{array}$ & $\begin{array}{l}-22.4 \\
-20.8\end{array}$ & $\begin{array}{l}22 \\
29\end{array}$ & & \\
\hline
\end{tabular}

In 2 hypertensive subjects with moderate digital vasodilatation, marked vasodilatation was induced locally in the nail fold by pricking in histamine. Vasoconstrictor stimuli applied at the height of the resulting erythema were still followed by decreases $(2 \mathrm{~mm}$. $\mathrm{Hg}$ to $5 \mathrm{~mm} . \mathrm{Hg}$ ) in the capillary blood pressure (Table I).

The above changes in capillary blood pressure were never accompanied by visible alterations in the diameter of the capillaries or in the flow of blood through them.

\section{B. Subjects with abnormally large capillaries}

Each of the 7 patients in this group had either Raynaud's disease, or scleroderma, or both, involving the fingers. Only in subject $M$. B. were the capillaries of approximately normal size; in all other subjects, they were unquestionably abnormally large.

\section{Intact sympathetic innervation}

Neurogenic vasoconstriction. With the digital circulation in moderate vasodilatation, neurogenic 
vasoconstrictor stimuli were administered 89 times to 7 subjects (Table II). Following 52 stimuli, the capillary blood pressure decreased (Figure 1A, Figure 2A) by $1 \mathrm{~mm}$. $\mathrm{Hg}$ to $8 \mathrm{~mm}$. $\mathrm{Hg}$ (4.4 to 27.8 per cent). These falls in pressure persisted for 5 to 65 seconds. After 29 stimuli the capillary blood pressure remained essentially unchanged (Figure 3 ); and on the remaining 8 occasions, it rose slightly $(1 \mathrm{~mm}$. $\mathrm{Hg}$ to 2 $\mathrm{mm} . \mathrm{Hg}$ ). The stimuli which were followed by no change or a slight rise in capillary blood pressure, usually induced slight digital vasoconstrictions of short duration, or none at all. On one occasion, however, an increase in pressure of 5 $\mathrm{mm}$. $\mathrm{Hg}$ accompanied a substantial vasoconstriction. Two subjects (M. S. and M. B.) accounted for 7 of the 8 instances in which the capillary blood pressure rose during digital vasoconstriction.

Usually, the more marked decreases in capillary blood pressure accompanied the more marked and more prolonged vasoconstrictions (Table II). There were exceptions. For example, in patient C. M., a deep breath was, on one occasion, followed by a fall of $8 \mathrm{~mm}$. $\mathrm{Hg}$ in the capillary pressure, although the simultaneously recorded digital vasoconstriction was slight. In patient $F$. G., ice applied to the face induced, on one occasion, a marked digital vasoconstriction, during which the capillary blood pressure remained unaltered.

Although vasoconstrictions occasionally were not accompanied by significant changes in capillary blood pressure (Figure 3), decreases in capil-

TABLE II

Change in capillary blood pressure during vasoconstriction induced by " neurogenic" vasoconstrictor stimuli. Dilated capillaries. Intact innervation

\begin{tabular}{|c|c|c|c|c|c|c|c|c|c|c|c|}
\hline \multirow{2}{*}{$\begin{array}{l}\text { Subject } \\
\text { (Sex, } \\
\text { age) }\end{array}$} & \multirow{2}{*}{ Diagnosis } & \multirow{2}{*}{$\begin{array}{c}\text { Arterial } \\
\text { pres- } \\
\text { sure }\end{array}$} & \multirow{2}{*}{\begin{tabular}{|} 
Skin \\
temper- \\
ature
\end{tabular}} & \multirow{2}{*}{$\begin{array}{l}\text { Location in } \\
\text { capillary } \\
\text { where } \\
\text { pressure was } \\
\text { measured }\end{array}$} & \multicolumn{3}{|c|}{ Capillary blood pressure } & \multirow{2}{*}{$\begin{array}{l}\text { Dura- } \\
\text { tion of } \\
\text { change } \\
\text { in cap- } \\
\text { illary } \\
\text { blood } \\
\text { pressure }\end{array}$} & \multirow{2}{*}{$\begin{array}{l}\text { Magni- } \\
\text { tude of } \\
\text { vasocon- } \\
\text { striction } \\
\text { by ple- } \\
\text { thysmo- } \\
\text { graphy }\end{array}$} & \multirow{2}{*}{ Stimulus } & \multirow{2}{*}{ Remarks } \\
\hline & & & & & Initial & $\begin{array}{l}\text { Maximun } \\
\text { due to of }\end{array}$ & $\begin{array}{l}\text { change } \\
\text { imulus }\end{array}$ & & & & \\
\hline \multirow[t]{3}{*}{$\left(\begin{array}{l}\mathbf{T} . \mathbf{A} \\
\mathbf{M}, \mathbf{2 6})\end{array}\right.$} & \multirow[t]{3}{*}{ Scleroderma } & \multirow[t]{3}{*}{$\begin{array}{r}\mathrm{mm} . \mathrm{Bt} \\
90 / 56\end{array}$} & \multirow[t]{3}{*}{$\begin{array}{l}{ }^{\circ} C . \\
31.1\end{array}$} & \multirow{3}{*}{ 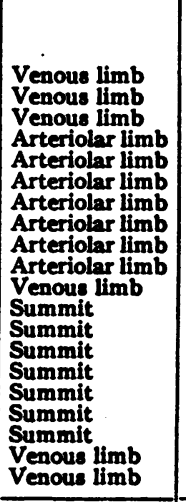 } & \multirow{3}{*}{\begin{tabular}{|l|}
$m m . B 8$ \\
18.5 \\
18.5 \\
18.5 \\
22 \\
22 \\
21 \\
22 \\
22 \\
22 \\
23 \\
13 \\
14 \\
14 \\
14 \\
14 \\
15.5 \\
15 \\
15 \\
16 \\
18 \\
\end{tabular}} & \multirow{3}{*}{\begin{tabular}{|c|}
$m m . B_{2}$ \\
0 \\
-3 \\
-2 \\
-3.5 \\
-4 \\
-2 \\
-5 \\
-5 \\
0 \\
-3.5 \\
-2 \\
-1 \\
-1.5 \\
0 \\
0 \\
-3 \\
-2 \\
-2.5 \\
-2 \\
-1
\end{tabular}} & \multirow{3}{*}{$\begin{array}{c}\text { per cent } \\
\text { of } \\
\text { inilial } \\
0 \\
-16.2 \\
-10.2 \\
-15.9 \\
-18.9 \\
-18.2 \\
-9.5 \\
-22.7 \\
-22.7 \\
0 \\
-15.2 \\
-15.4 \\
-7.1 \\
-10.7 \\
0 \\
-19 \\
-19.3 \\
-13.3 \\
-16.6 \\
-12.5 \\
-5.6\end{array}$} & \multirow[t]{3}{*}{$\begin{array}{c}\text { seconds } \\
\\
57 \\
65 \\
35 \\
60 \\
35 \\
15+ \\
51 \\
35 \\
30 \\
7 \\
15\end{array}$} & \multirow[b]{3}{*}{$\begin{array}{l}3+ \\
2+ \\
3+ \\
2+ \\
1+\end{array}$} & \multirow{3}{*}{$\begin{array}{l}\text { Ice to leg } \\
\text { Deep breath } \\
\text { Deep breath } \\
\text { Ice to leg } \\
\text { Ice to leg } \\
\text { Ice to leg } \\
\text { Deep breath } \\
\text { Deep breath } \\
\text { Mental problem } \\
\text { Deep breath } \\
\text { Deep breath } \\
\text { Deep breath } \\
\text { Deep breath } \\
\text { Ice to les } \\
\text { Ice to neck } \\
\text { Ice } \\
\text { Pin prick } \\
\text { Ice } \\
\text { Pin prick } \\
\text { Mental problem }\end{array}$} & \multirow{3}{*}{$\begin{array}{l}\text { After intradermal } \\
\text { histamine } \\
(1: 100)\end{array}$} \\
\hline & & & & & & & & & & & \\
\hline & & & & & & & & & & & \\
\hline (F. B. & $\begin{array}{l}\text { Scleroderma } \\
\text { with } \\
\text { Raynaud's } \\
\text { Disence }\end{array}$ & $110 / 76$ & 25.3 & $\begin{array}{l}\text { Venous } \operatorname{limb} \\
\text { Venous } \operatorname{limb}_{\text {Venoug }} \operatorname{limb} \\
\text { Summit } \\
\text { Summit } \\
\text { Summit }\end{array}$ & $\begin{array}{l}17 \\
16.5 \\
16.5 \\
19 \\
18 \\
20 \\
\end{array}$ & $\begin{array}{l}-4 \\
-0 \\
-3 \\
-4 \\
-3 \\
-5\end{array}$ & $\begin{array}{r}-23.5 \\
0 \\
-18.2 \\
-21.0 \\
-16.7 \\
-25.0\end{array}$ & $\begin{array}{l}35 \\
20 ? \\
15 \\
15 \\
15\end{array}$ & & $\begin{array}{l}\text { Ice to les } \\
\text { Pin prick } \\
\text { Deep breath } \\
\text { Deep breath } \\
\text { Ice to les } \\
\text { Deep breath }\end{array}$ & \\
\hline (F. B. & $\begin{array}{c}\text { Scleroderma } \\
\text { with } \\
\text { Raynaud's } \\
\text { Disease }\end{array}$ & $124 / 86$ & 25.0 & $\begin{array}{l}\text { Venous } \operatorname{limb} \\
\text { Venous } \operatorname{limb}\end{array}$ & $\begin{array}{l}17 \\
19\end{array}$ & +2.5 & $\begin{array}{l}+29.4 \\
+10.5 \\
+13.1\end{array}$ & $\begin{array}{l}22+ \\
10 \\
15\end{array}$ & $2+$ & $\begin{array}{l}\text { Pin prick } \\
\text { Ice to face }\end{array}$ & $\begin{array}{l}\text { Capllarifes of "top } \\
\text { normal" aize }\end{array}$ \\
\hline (F. S. 17) & $\begin{array}{l}\text { Raymaud's } \\
\text { Diseave }\end{array}$ & $86 / 50$ & 30.0 & 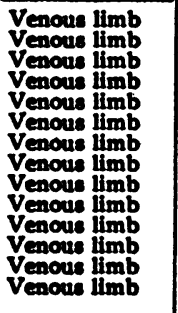 & $\begin{array}{l}18 \\
18 \\
18 \\
18 \\
18 \\
19 \\
18.5 \\
18 \\
19 \\
18 \\
18.5 \\
18.5 \\
17 \\
16\end{array}$ & $\begin{array}{l}-0.5 \\
0.5 \\
+1 \\
+1 \\
+0.5 \\
-0.5 \\
+0.5 \\
+1 \\
+1 \\
+2 \\
0 \\
+0.5 \\
-3 \\
0\end{array}$ & $\begin{array}{l}-2.8 \\
0 \\
+5.6 \\
+5.6 \\
\pm 2.8 \\
+2.6 \\
+2.7 \\
+5.6 \\
+5.3 \\
+11.1 \\
0.1 \\
+2.7 \\
-17.6\end{array}$ & $\begin{array}{l}15 \\
10 \\
15 \\
10 \\
25\end{array}$ & $\begin{array}{l}? \\
1 \pm \\
1+ \\
1 \pm \\
\pm+ \\
1 \pm \\
1 \pm \\
0 \\
1 \pm \\
\pm \\
\pm\end{array}$ & $\begin{array}{l}\text { Ice to shoulder } \\
\text { Deep breath } \\
\text { Pin prick } \\
\text { Ice to neck } \\
\text { Ice to ghoulder } \\
\text { Deep breath } \\
\text { Pin prick } \\
\text { Deep breath } \\
\text { Ice to neck } \\
\text { Deep breath } \\
\text { Pin prick } \\
\text { Meptal problem } \\
\text { Deep breath } \\
\text { Deep breath }\end{array}$ & \\
\hline
\end{tabular}


TABLE II-Continued



lary blood pressure were unusual in the absence of demonstrable vasoconstrictions.

During similar states of the digital circulation, as judged by the digital skin temperature, a given vasoconstrictor stimulus did not always induce the same degree of change either in the digital volume or in the digital capillary blood pressure. This maintained for different individuals and even in a series of observations on a single capillary (Table II).

Vasoconstriction induced by epinephrin injected intravenously. Epinephrin hydrochloride ( 1 to 2.5 gamma) was injected intravenously into 5 subjects. Strong digital vasoconstrictions followed 10 of the 11 injections; once the response was equivocal. A fall in capillary blood pressure accompanied 7 of the 10 vasoconstrictions (Table III, Figure 1B). Between injection and initiation of vasoconstriction, 10 to $\mathbf{4 5}$ seconds elapsed (Figure 1B). This probably represented the time required for the epinephrin to reach the digit. The magnitude and duration of the decreases in digital volume and the associated falls in capillary blood pressure (1.5 to $22 \mathrm{~mm}$. $\mathrm{Hg}, 12.5$ to 58.5 per cent) (Table III) appeared to be more marked than those observed after neurogenic vasoconstrictor stimuli.

Small rises in the capillary blood pressure (1.5 $\mathrm{mm}$. $\mathrm{Hg}$ to $2.0 \mathrm{~mm}$. $\mathrm{Hg}$ ) occurred with 3 of the 10 vasoconstrictions. Twice this occurred in subject M. S., in whom slight rises in capillary blood pressure also accompanied neurogenic vasocon- 

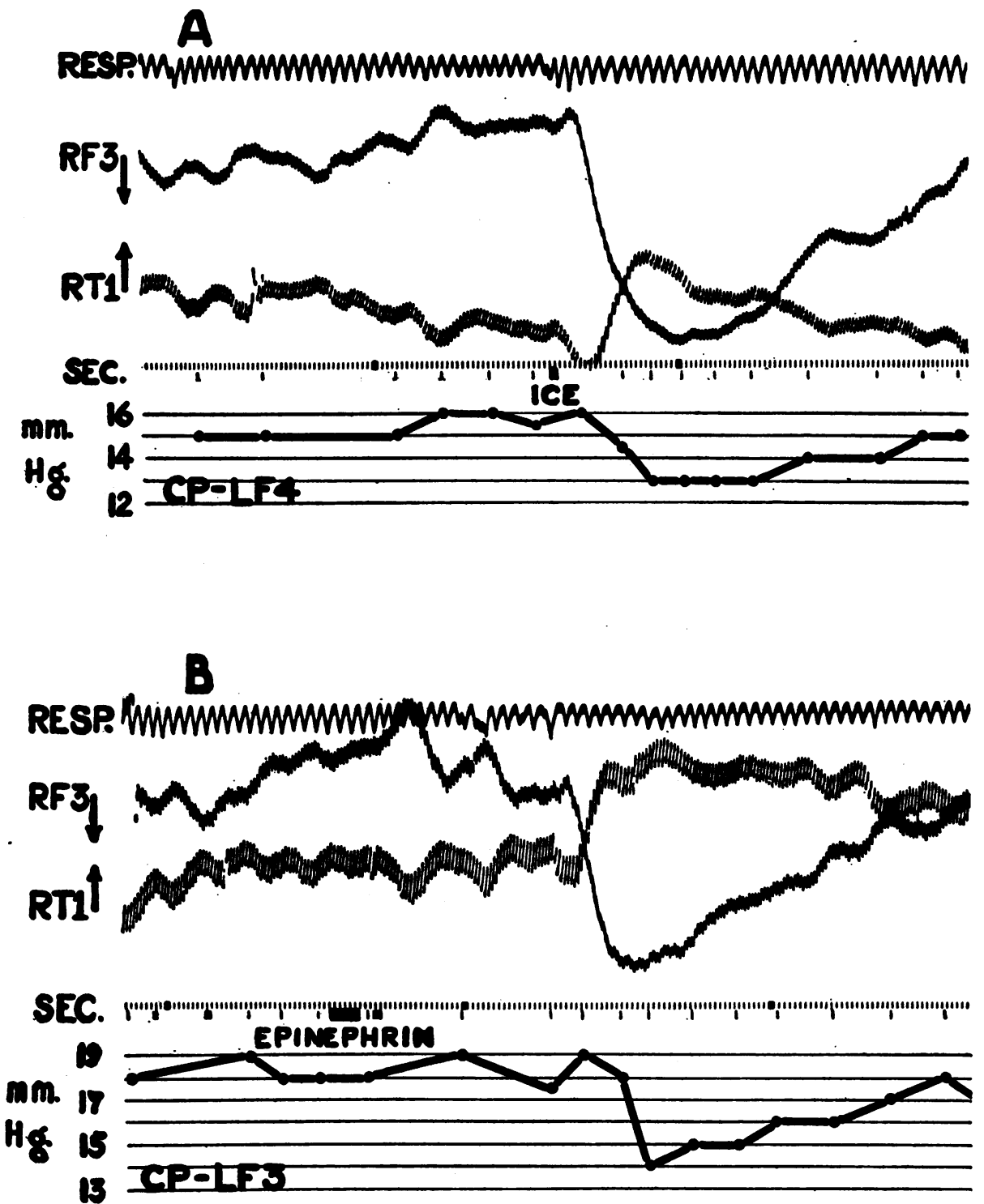

Fig. 1. Subject T. A. Moderate Scleroderma of Hands. Innervation of All Digits Intact In Both A AND B

A. Simultaneous changes in capillary blood pressure and digital volume during vasoconstriction induced by ice to the skin. Capillary blood pressure measured in the summit of a capillary loop. Skin temperature LF 4, 27.5 $\mathrm{C}$. Room temperature, $23.7^{\circ} \mathrm{C}$. Arterial pressure, left arm 102/72 $\mathrm{mm}$. Hg.

B. Simultaneous changes in capillary blood pressure and digital volume during vasoconstriction induced by the intravenous injection of 1 gamma of epinephrin hydrochloride. Capillary blood pressure measured in the venous limb of a capillary loop. Skin temperature LF 3, $30^{\circ}$ C. Room temperature, $24.6^{\circ}$ C. Arterial pressure, left arm 104/72 mm. Hg. (3 signal marks indicate beginning of "needling"; 4 marks, entry of needle into vein; solid mark, injection; 5 marks, withdrawal of the needle.)

All figures are similarly plotted and labelled. From above downward they record respectively: RESP.-respiration, the down stroke indicating inspiration. $R F 3 \downarrow, R T 1 \uparrow$ (or other letters)-digital pulse wave and digital volume, the arrow indicating the direction of a decrease in volume. SEC.-time interval in seconds, the solid mark indicating the minute 
strictions. During the one equivocal response, the capillary blood pressure fell $3 \mathrm{~mm}$. $\mathrm{Hg}$.

\section{Sympathetic innervation interrupted}

Neurogenic vasoconstriction. Except on one occasion, when a small digital vasoconstriction followed the stimulus of mental arithmetic, ${ }^{2}$ neurogenic vasoconstrictor stimuli (13 in all) failed to induce any change in the capillary blood pressure or in the volume of the sympathectomized digits of three subjects (Table IV, Figure 2B). During the one small vasoconstriction, capillary blood pressure increased $1 \mathrm{~mm}$. $\mathrm{Hg}$. In each subject, the same stimuli produced definite vasoconstrictions in the contralateral, normally innervated digits (Figure 2B).

Vasoconstriction induced by epinephrin injected intravenously. Epinephrin hydrochloride (1 to 2 gamma) was administered intravenously 9 times to 3 subjects, with temporarily or permanently interrupted sympathetic innervation of the digits (Table V). On each occasion, after the usual latent period, similar decreases in digital volume were recorded in both the sympathectomized and in the contralateral, normally innervated digits. In the sympathectomized digits, the vasoconstrictions were accompanied by falls in capillary blood pressure which in duration (15 to 60 seconds) and magnitude $(1 \mathrm{~mm}$. $\mathrm{Hg}$ to $11 \mathrm{~mm}$. $\mathrm{Hg}, 6.3$ to 35.5 per cent) approximated those observed in the normally innervated digit (Table $V$, Figure 4A, Figure 4B).

\section{Relation between capillary blood pressure and changes in volume of digit}

Although usually paralleling the decreases in digital volume, the falls in capillary blood pressure

2 Recent evidence (9) indicates that a humoral (epinephrin-like) component may be involved in the production of the digital vasoconstriction induced by mental arithmetic. The effect of epinephrin in sympathectomized digits is discussed subsequently. appeared at times to lag behind the changes in volume. Thus, during the initial phase of vasoconstriction, when the digital volume was decreasing most rapidly, the capillary blood pressure occasionally remained unchanged, or even increased slightly (Figure 1B). As the digital volume reached its lowest level, the capillary blood pressure also fell but occasionally did not attain its lowest value until after the digital volume had begun to increase toward its original level. The capillary blood pressure returned to its initial value more slowly than the digital volume. Such lags in capillary blood pressure behind the changes in digital volume were observed during vasoconstrictions induced by both epinephrin and neurogenic vasoconstrictor stimuli, and in sympathectomized as well as in normally innervated digits.

In all of the experiments, the changes in capillary blood pressure tended to be qualitatively the same in all parts of the capillary: arteriolar limb, summit, and venous limb.

\section{DISCUSSION}

It has previously been shown that digital capillary blood pressure is readily altered by changes in both the local $(3,4)$ and systemic (10) venous pressures, by the injection of histamine locally (3), and by the local application of heat and cold (3). Employing direct measurement, this study adds information concerning the effect upon capillary blood pressure of vasoconstrictions caused by reflex nervous mechanism and by a circulating pressor substance. This information was desired before proceeding to a comparison of capillary blood pressure in normal and hypertensive subjects (11).

Although capillary blood pressure in the nailfolds did fall during neurogenically induced digital vasoconstrictions, these reductions in pressure were relatively small: never exceeding 33.3 per cent of the initial value. Rarely, did the resultant

interval. The signal marks immediately below the time tracing indicate the exact time of a capillary blood pressure determination (single thin mark) and the time and duration of the administration of the stimulus noted immediately below (solid mark). All of the above is the actual optical record. Below this record and upon the same time axis is plotted the capillary blood pressure ( CP-LF4, or similar legend) in $\mathrm{mm}$. $\mathrm{Hg}$. Each plotted point of capillary blood pressure represents the pressure at the time of the signal mark immediately above.

Digits are identified by the recognized scheme: the first letter indicating the side (right or left); the second letter, the digit (finger or toe) and the number the specific digit (first, second, etc.). 
capillary blood pressure fall beyond the limits obtained under resting conditions. When compared with the reductions induced in digital blood flow during similar vasoconstrictions, the percentile decreases in capillary blood pressure are considerably smaller. For example, Wilkins, Doupe, and Newman (1) found that during neurogenic vasoconstrictions "the flow to the fingers may be temporarily decreased as much as 20 times," and Burton (2) states that "a deep breath causes momentary almost complete cessation of flow in the fingers." Conversely, during reflex vasodilatation the blood flow to the fingers may increase as much as 100 times (1), but during similar condi-
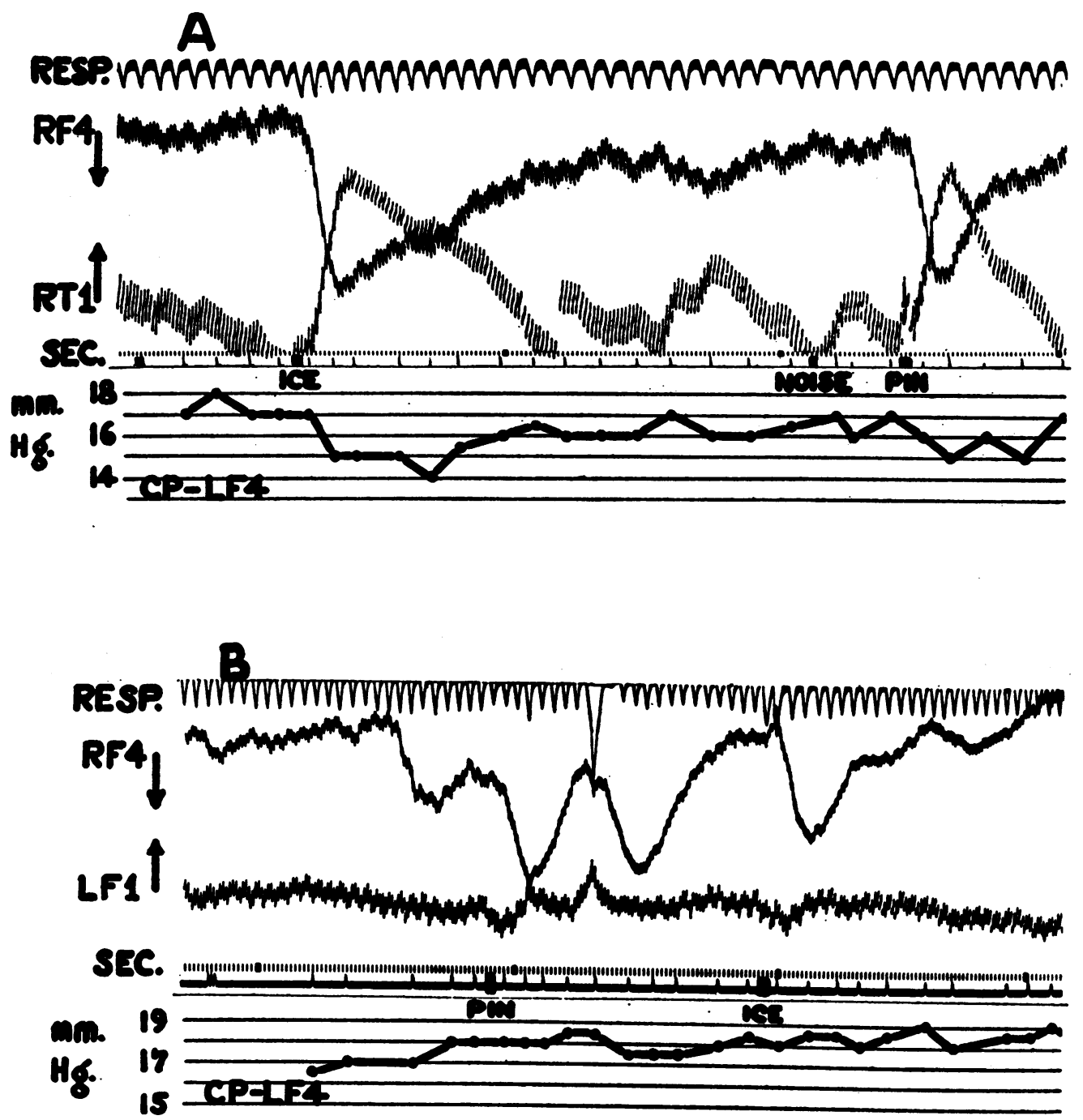

Fig. 2. Subject F. G. Raynaud's Disease of Hands and Feet

A. Simultaneous changes in capillary blood pressure and digital volume during vasoconstrictions induced by ice and pin prick. Digital innervation intact. Capillary blood pressure measured at junction of venous limb and summit of a capillary loop. Skin temperature LF4, 30 ${ }^{\circ}$ C. Room temperature, $25.5^{\circ}$

C. Arterial pressure left arm $122 / 88 \mathrm{~mm}$. Hg.

B. Simultaneous observations of capillary blood pressure in a sympathectomized digit and of digital volume in a sympathectomized and in a normally innervated digit, during application of vasoconstrictor stimuli. Preganglionic sympathectomy of left upper extremity. Intact innervation right upper extremity. Capillary blood pressure measured at junction of venous limb and summit of a capillary loop. Skin temperature LF4, $31.5^{\circ} \mathrm{C}$. Room temperature, $26.3^{\circ} \mathrm{C}$. Arterial pressure, left arm $110 / 80 \mathrm{~mm}$. Hg. Note spontaneous deep breath between stimuli of pin prick and ice. 

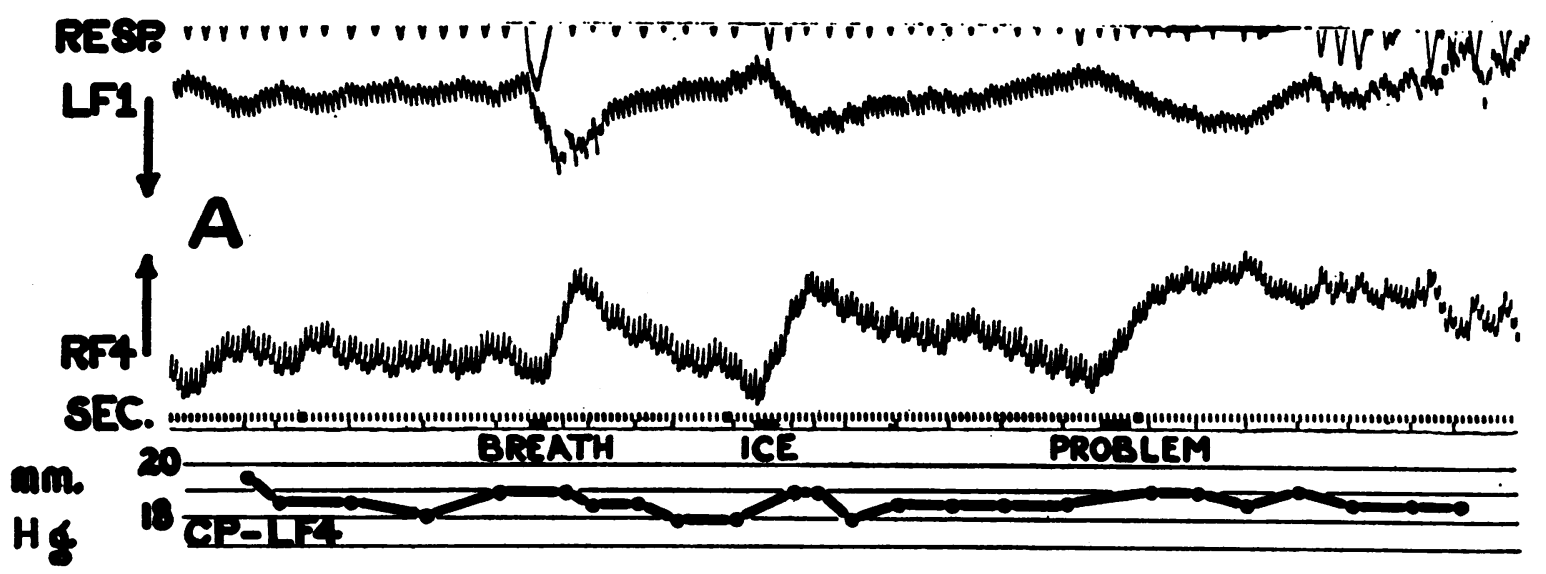

Fig. 3. Subject M. S. Raynaud's Disease with Sçleroderma of Hands and Feet

Simultaneous observations of capillary blood pressure and of digital volume during vasoconstrictions induced by deep breath, ice to the skin, and mental arithmetic. Digital innervation intact. Capillary blood pressure measured in the venous limb of a capillary. Skin temperature LF4, $29.2^{\circ} \mathrm{C}$. Room temperature $24.5^{\circ} \mathrm{C}$. Arterial pressure, left arm $86 / 50 \mathrm{~mm}$. $\mathrm{Hg}$.

tions no comparable increase in capillary blood pressure was found in this or in other studies (11).

There appears to be a homeostatic mechanism which keeps the digital capillary blood pressure within relatively narrow limits, even though blood flow in the digits is undergoing wide fluctuations during digital vasoconstriction. The arteriolevenule anastomoses in the digits may contribute one component to this mechanism. .By shunting blood through these structures, and by-passing the capillaries, wide variations in digital blood flow could occur without great changes in capillary blood pressure.

TABLE III

Change in capillary blood pressure during vasoconstriction induced by epinephrin intravenously. Abnormally large capillaries. Intact innervation

\begin{tabular}{|c|c|c|c|c|c|c|c|c|c|c|}
\hline \multirow{2}{*}{$\begin{array}{l}\text { Subject } \\
\text { (Sex. } \\
\text { age) }\end{array}$} & \multirow{2}{*}{ Diagnosis } & \multirow{2}{*}{$\begin{array}{l}\text { Arterial } \\
\text { pres- } \\
\text { sure }\end{array}$} & \multirow{2}{*}{$\begin{array}{l}\text { Skin } \\
\text { temper- } \\
\text { ature }\end{array}$} & \multirow{2}{*}{$\begin{array}{l}\text { Location in } \\
\text { capillary } \\
\text { where } \\
\text { pressure was } \\
\text { measured }\end{array}$} & \multicolumn{3}{|c|}{ Capillary blood pressure } & \multirow{2}{*}{$\begin{array}{l}\text { Duration of } \\
\text { change in } \\
\text { capillary } \\
\text { blood } \\
\text { pressure }\end{array}$} & \multirow{2}{*}{$\begin{array}{l}\text { Magni- } \\
\text { tude } \\
\text { of } \\
\text { vasocon- } \\
\text { striction }\end{array}$} & \multirow{2}{*}{ Stimulus } \\
\hline & & & & & Initial & $\begin{array}{l}\text { Maximun } \\
\text { due to } s\end{array}$ & $\begin{array}{l}\text { change } \\
\text { timulus }\end{array}$ & & & \\
\hline $\begin{array}{c}\text { T. A. } \\
(\mathbf{M}, 26)\end{array}$ & Scleroderma & $\begin{array}{l}m m . H_{l} \\
102 / 72 \\
102 / 72 \\
102 / 72 \\
102 / 72\end{array}$ & $\begin{array}{l}{ }^{\circ} C . \\
28.5 \\
28.5 \\
28.5 \\
28.5\end{array}$ & $\begin{array}{l}\text { Summit } \\
\text { Summit } \\
\text { Venous limb } \\
\text { Venous limb }\end{array}$ & $\begin{array}{c}\text { mm. } H_{\ell} \\
19 \\
18 \\
16 \\
18\end{array}$ & $\begin{array}{l}m m . H_{g} \\
-10 \\
=3 \\
-5+ \\
-4\end{array}$ & $\begin{array}{c}\text { per cent } \\
\text { of } \\
\text { initial } \\
-52.7 \\
-16.7 \\
-31.2 \\
-22.2\end{array}$ & $\begin{array}{l}\text { seconds } \\
98+ \\
21 \\
15+ \\
40\end{array}$ & $\begin{array}{l}4+ \\
3+ \\
4+ \\
3+\end{array}$ & $\begin{array}{l}\text { Epinephrin } 2 \gamma \\
\text { Epinephrin } 1 \gamma \\
\text { Epinephrin } 2.5 \gamma \\
\text { Epinephrin } 1 \gamma\end{array}$ \\
\hline $\begin{array}{l}\text { M. B. } \\
(\mathbf{F}, 47)\end{array}$ & $\begin{array}{l}\text { Scleroderma } \\
\text { Raynaud's } \\
\text { Disease }\end{array}$ & $124 / 86$ & 25.0 & Venous limb & 37.5 & $-22 ?$ & -58.8 & $60+$ & $2+$ & Epinephrin $1 \gamma$ \\
\hline$\underset{(\mathbf{M}, \mathbf{3 8})}{\mathbf{F} .}$ & Scleroderma & $118 / 62$ & 30.7 & Summit & 38 & -8 & -21.0 & $10+$ & $3+$ & Epinephrin $2 \gamma$ \\
\hline $\begin{array}{l}\text { M. S. } \\
(\mathbf{F}, 17)\end{array}$ & $\begin{array}{l}\text { Raynaud's } \\
\text { Disease }\end{array}$ & $\begin{array}{l}86 / 50 \\
86 / 50\end{array}$ & $\begin{array}{l}30.0 \\
30.0\end{array}$ & $\begin{array}{l}\text { Venous limb } \\
\text { Venous limb }\end{array}$ & $\begin{array}{l}16 \\
15\end{array}$ & $\begin{array}{l}+1.5 \\
+2\end{array}$ & $\begin{array}{r}+9.4 \\
+13.3\end{array}$ & $?$ & $\begin{array}{l}1+ \\
2+\end{array}$ & $\begin{array}{l}\text { Epinephrin } 1 \gamma \\
\text { Epinephrin } 1 \gamma\end{array}$ \\
\hline $\begin{array}{l}\text { C. M. } \\
(\mathbf{F}, 29)\end{array}$ & $\begin{array}{l}\text { Raynaud's } \\
\text { Disease }\end{array}$ & $\begin{array}{l}128 / 86 \\
128 / 86 \\
128 / 86\end{array}$ & $\begin{array}{l}27.0 \\
32.1 \\
32.1\end{array}$ & $\begin{array}{l}\text { Summit } \\
\text { Venous limb } \\
\text { Summit }\end{array}$ & $\begin{array}{l}16 \\
20 \\
24\end{array}$ & $\begin{array}{l}-3 \\
+2 \\
-3\end{array}$ & $\begin{array}{l}-18.7 \\
+10.0 \\
-12.5\end{array}$ & $\begin{array}{c}? \\
25+\end{array}$ & $\begin{array}{l}? \\
2+ \\
1+\end{array}$ & $\begin{array}{l}\text { Epinephrin } 1 \gamma \\
\text { Epinephrin } 1 \gamma \\
\text { Epinephrin } 1 \gamma\end{array}$ \\
\hline \multicolumn{2}{|c|}{ Average } & & & & & -4.8 & -18.3 & 38.5 & & \\
\hline
\end{tabular}


TABLE IV

Capillary blood pressure during " neurogenic" vasoconstrictor stimuli. Abnormally large capillaries. Sympathetic innervation interrupted

\begin{tabular}{|c|c|c|c|c|c|c|c|c|c|c|c|}
\hline \multirow{3}{*}{$\begin{array}{c}\begin{array}{c}\text { Subject } \\
\text { (Sex. } \\
\text { age) }\end{array} \\
\begin{array}{c}\text { F. H. } \\
(\mathbf{M}, 38)\end{array}\end{array}$} & \multirow{3}{*}{$\begin{array}{c}\text { Diagnosis } \\
\text { Scleroderma }\end{array}$} & \multirow{3}{*}{$\begin{array}{c}\begin{array}{c}\text { Arterial } \\
\text { pres- } \\
\text { sure }\end{array} \\
\begin{array}{c}m m . H g \\
118 / 62\end{array}\end{array}$} & \multirow{3}{*}{\begin{tabular}{|l|}
$\begin{array}{l}\text { Skin } \\
\text { tem- } \\
\text { pera- } \\
\text { ture }\end{array}$ \\
${ }^{\circ} C$. \\
30.7
\end{tabular}} & \multirow{3}{*}{$\begin{array}{c}\text { Location } \\
\text { in } \\
\text { capillary } \\
\text { where } \\
\text { pressure } \\
\text { was } \\
\text { measured }\end{array}$} & \multicolumn{3}{|c|}{$\begin{array}{l}\text { Capillary blood } \\
\text { pressure }\end{array}$} & \multirow{3}{*}{\begin{tabular}{|c|}
$\begin{array}{c}\text { Dura- } \\
\text { tion of } \\
\text { change } \\
\text { in cap } \\
\text { illary } \\
\text { blood } \\
\text { pressure }\end{array}$ \\
seconds \\
$?$
\end{tabular}} & \multirow{3}{*}{$\begin{array}{c}\begin{array}{c}\text { Magni- } \\
\text { tude } \\
\text { of } \\
\text { vasocon- } \\
\text { striction }\end{array} \\
\\
0\end{array}$} & \multirow{3}{*}{$\begin{array}{r}\text { Stimulus } \\
\text { Ice to leg }\end{array}$} & \multirow{3}{*}{$\begin{array}{l}\text { Remarks } \\
\\
\text { Paravertebral } \\
\text { block. Capillary } \\
\text { pressure remained } \\
\text { at lower figure }\end{array}$} \\
\hline & & & & & \multirow{2}{*}{ 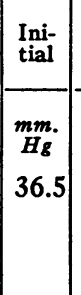 } & \multicolumn{2}{|c|}{$\begin{array}{l}\text { Maximum } \\
\text { change due } \\
\text { to stimulus }\end{array}$} & & & & \\
\hline & & & & & & $\begin{array}{c}\underset{H \boldsymbol{g}}{\mathrm{m} .} \\
-2.5\end{array}$ & $\mid \begin{array}{c}\text { per cent } \\
\text { of } \\
\text { initial } \\
-6.8\end{array}$ & & & & \\
\hline$\underset{(\mathrm{F}, 17)}{\mathrm{M} . \mathrm{S}}$ & $\begin{array}{l}\text { Raynaud's } \\
\text { Disease }\end{array}$ & $\begin{array}{l}86 / 50 \\
86 / 50 \\
86 / 50 \\
86 / 50 \\
86 / 50 \\
86 / 50 \\
86 / 50 \\
86 / 50\end{array}$ & \begin{tabular}{|l|}
33.9 \\
33.9 \\
33.9 \\
33.9 \\
33.9 \\
33.9 \\
33.9 \\
33.9
\end{tabular} & $\begin{array}{l}\text { Summit } \\
\text { Summit } \\
\text { Summit } \\
\text { Summit } \\
\text { Summit } \\
\text { Summit } \\
\text { Summit } \\
\text { Summit }\end{array}$ & \begin{tabular}{l|}
17 \\
18 \\
18 \\
17.5 \\
17.5 \\
17 \\
17 \\
17 \\
\end{tabular} & $\begin{array}{c}0 \\
0 \\
0 \\
0 \\
0 \\
0 \\
0 \\
+1.0 \\
\end{array}$ & $\begin{array}{c}0 \\
0 \\
0 \\
0 \\
0 \\
0 \\
0 \\
+5.9 \\
\end{array}$ & 54 & $\begin{array}{c}0 \\
0 \\
\text { Moved } \\
0 \\
0 \\
0 \\
\text { Moved } \\
1+\end{array}$ & $\begin{array}{l}\text { Ice to shoulder } \\
\text { Pin prick } \\
\text { Deep breath } \\
\text { Ice to shoulder } \\
\text { Pin prick } \\
\text { Deep breath } \\
\text { Ice } \\
\text { Mental problem }\end{array}$ & $\begin{array}{l}\text { Paravertebral } \\
\text { block }\end{array}$ \\
\hline $\begin{array}{l}\text { F. G. } \\
(M, 32)\end{array}$ & $\begin{array}{l}\text { Raynaud's } \\
\text { Disease }\end{array}$ & $\begin{array}{l}110 / 80 \\
110 / 80 \\
110 / 80 \\
110 / 80 \\
110 / 80\end{array}$ & $\begin{array}{l}31.9 \\
31.9 \\
31.9 \\
31.9 \\
31.9\end{array}$ & $\begin{array}{l}\text { Summit } \\
\text { Summit } \\
\text { Summit } \\
\text { Summit } \\
\text { Summit }\end{array}$ & \begin{tabular}{|l|}
18 \\
18.5 \\
18.5 \\
21.5 \\
21.5
\end{tabular} & $\begin{array}{l}\mathbf{0} \\
\mathbf{0} \\
\mathbf{0} \\
\mathbf{0} \\
\mathbf{0}\end{array}$ & $\begin{array}{l}0 \\
0 \\
0 \\
0 \\
0\end{array}$ & & $\begin{array}{l}0 \\
0 \\
0 \\
0 \\
0\end{array}$ & $\begin{array}{l}\text { Pin prick } \\
\text { Ice to face } \\
\text { Ice } \\
\text { Pin prick } \\
\text { Ice }\end{array}$ & $\begin{array}{l}\text { Preganglionic } \\
\text { sympathectomy }\end{array}$ \\
\hline
\end{tabular}

TABLE V

Change in capillary blood pressure during vasoconstriction induced by epinephrin intravenously. Abnormally large capillaries. Sympathetic innervation interrupted

\begin{tabular}{|c|c|c|c|c|c|c|c|c|c|c|c|}
\hline \multirow{2}{*}{$\begin{array}{l}\text { Subject } \\
\text { (Sex, } \\
\text { age) }\end{array}$} & \multirow{2}{*}{ Diagnosis } & \multirow{2}{*}{$\begin{array}{c}\text { Arterial } \\
\text { pres- } \\
\text { sure }\end{array}$} & \multirow{2}{*}{$\begin{array}{l}\text { Skin } \\
\text { tem- } \\
\text { pera- } \\
\text { ture }\end{array}$} & \multirow{2}{*}{$\begin{array}{l}\text { Location in } \\
\text { capillary } \\
\text { where } \\
\text { pressure was } \\
\text { measured }\end{array}$} & \multicolumn{3}{|c|}{ Capillary blood pressure } & \multirow{2}{*}{$\begin{array}{c}\text { Dura- } \\
\text { tion of } \\
\text { change } \\
\text { in } \\
\text { capil- } \\
\text { lary } \\
\text { blood } \\
\text { pres- } \\
\text { sure }\end{array}$} & \multirow{2}{*}{$\begin{array}{l}\text { Magni- } \\
\text { tude } \\
\text { of } \\
\text { vaso- } \\
\text { con- } \\
\text { stric- } \\
\text { tion }\end{array}$} & \multirow{2}{*}{ Stimulus } & \multirow{2}{*}{ Remarks } \\
\hline & & & & & $\begin{array}{l}\text { Ini- } \\
\text { tial }\end{array}$ & $\begin{array}{c}\text { Maximum } \\
\text { due to st }\end{array}$ & $\begin{array}{l}\text { change } \\
\text { imulus }\end{array}$ & & & & \\
\hline$\underset{(\mathrm{F}, \mathrm{M}}{\mathrm{M}} \mathbf{\mathrm { S }}$ & $\begin{array}{l}\text { Raynaud's } \\
\text { Disease }\end{array}$ & $\begin{array}{r}m m . \mathrm{Hg} \\
86 / 50 \\
86 / 50\end{array}$ & $\begin{array}{l}{ }^{\circ} \mathrm{C} . \\
33.9 \\
33.9\end{array}$ & $\begin{array}{l}\text { Summit } \\
\text { Summit }\end{array}$ & $\begin{array}{c}\operatorname{mm}_{H g} \\
16 \\
18\end{array}$ & $\begin{array}{l}m m . H_{g} \\
-1 \\
-3.5\end{array}$ & $\begin{array}{c}\text { per cent } \\
\text { of } \\
\text { initial } \\
-6.3 \\
-19.4\end{array}$ & $\begin{array}{l}\text { seconds } \\
15 \\
40\end{array}$ & $\begin{array}{l}1+ \\
2+\end{array}$ & $\begin{array}{l}\text { Epinephrin } 1 \gamma \\
\text { Epinephrin } 1 \gamma\end{array}$ & $\begin{array}{l}\text { Paravertebral block } \\
\text { Block wearing off }\end{array}$ \\
\hline $\begin{array}{l}\text { C. M. } \\
(\mathrm{F}, 29)\end{array}$ & $\begin{array}{l}\text { Raynäud's } \\
\text { Disease }\end{array}$ & $\begin{array}{l}128 / 86 \\
128 / 86 \\
112 / 76 \\
112 / 76 \\
112 / 76\end{array}$ & $\begin{array}{l}33.5 \\
33.5 \\
33.0 \\
35 \\
35\end{array}$ & $\begin{array}{l}\text { Arteriolar } \\
\text { limb } \\
\text { Arteriolar } \\
\text { limb } \\
\text { Summit } \\
\text { Venous limb } \\
\text { Venous limb }\end{array}$ & $\begin{array}{l}32.5 \\
25.5 \\
24 \\
29 \\
31\end{array}$ & $\begin{array}{c}? \\
-2 \\
+13.5 \\
\text { then }-2 \\
-4 \\
-11\end{array}$ & $\begin{array}{c}? \\
-7.8 \\
+56.3 \\
-8.3 \\
-13.8 \\
-35.5\end{array}$ & $\begin{array}{l}15 \\
30 \\
35 \\
25+\end{array}$ & $\begin{array}{l}2+ \\
2+ \\
2+ \\
1+ \\
2+\end{array}$ & 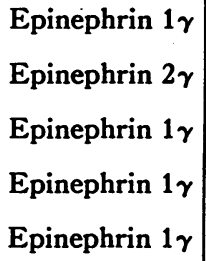 & $\begin{array}{l}\text { Preganglionic } \\
\text { sympathectomy }\end{array}$ \\
\hline$\underset{(\mathrm{M}, \mathrm{G})}{\mathrm{F} . \mathrm{G}}$ & $\begin{array}{l}\text { Raynaud's } \\
\text { Disease }\end{array}$ & $\begin{array}{l}110 / 80 \\
110 / 80\end{array}$ & $\begin{array}{l}33.5 \\
33.5\end{array}$ & $\begin{array}{l}\text { Venous limb } \\
\text { Summit }\end{array}$ & $\begin{array}{l}19.5 \\
20\end{array}$ & $\begin{array}{l}-3.5 \\
-4.0\end{array}$ & $\begin{array}{l}-18.0 \\
-20.0\end{array}$ & $\begin{array}{l}60 \\
30+\end{array}$ & $\begin{array}{l}4+ \\
4+\end{array}$ & $\begin{array}{l}\text { Epinephrin } 1 \gamma \\
\text { Epinephrin } 1 \gamma\end{array}$ & $\begin{array}{l}\text { Preganglionic } \\
\text { sympathectomy }\end{array}$ \\
\hline & erage & & & & & -2.6 & -16.1 & $31+$ & & & \\
\hline
\end{tabular}


Although of smaller magnitude, the falls in capillary blood pressure appeared to be directly related to the reductions in digital volume, and presumably in blood flow. Stimuli failing to induce reductions in digital volume caused no change in the capillary blood pressure; this was observed particularly after interruption of the sympathetic nervous pathways. Unless these pathways were intact, the capillary blood pressure was not altered by such neurogenic stimuli as the application of ice to a remote area of skin, pricking the skin with a pin, or the taking of a deep breath.' But even

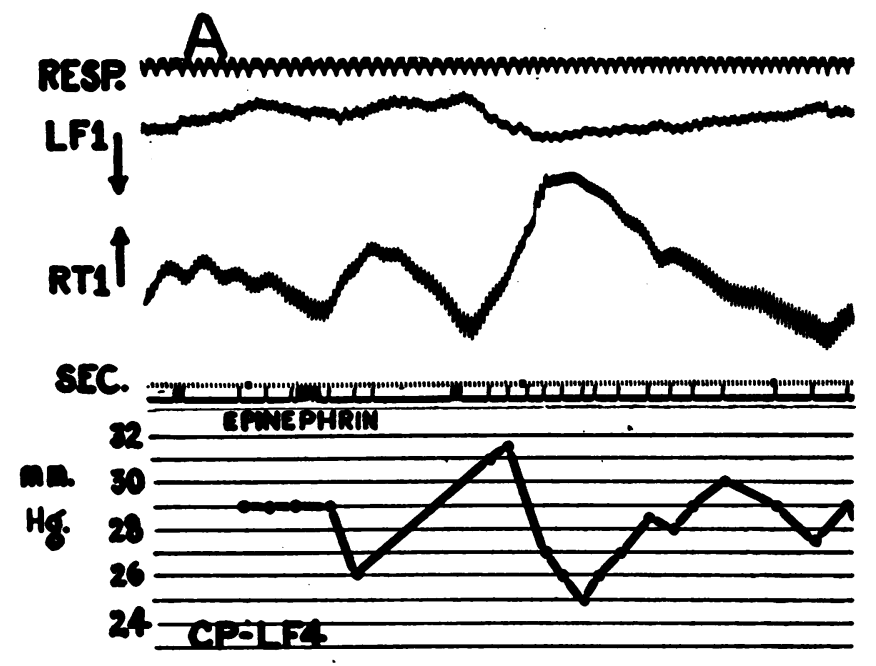

RERP B. B.

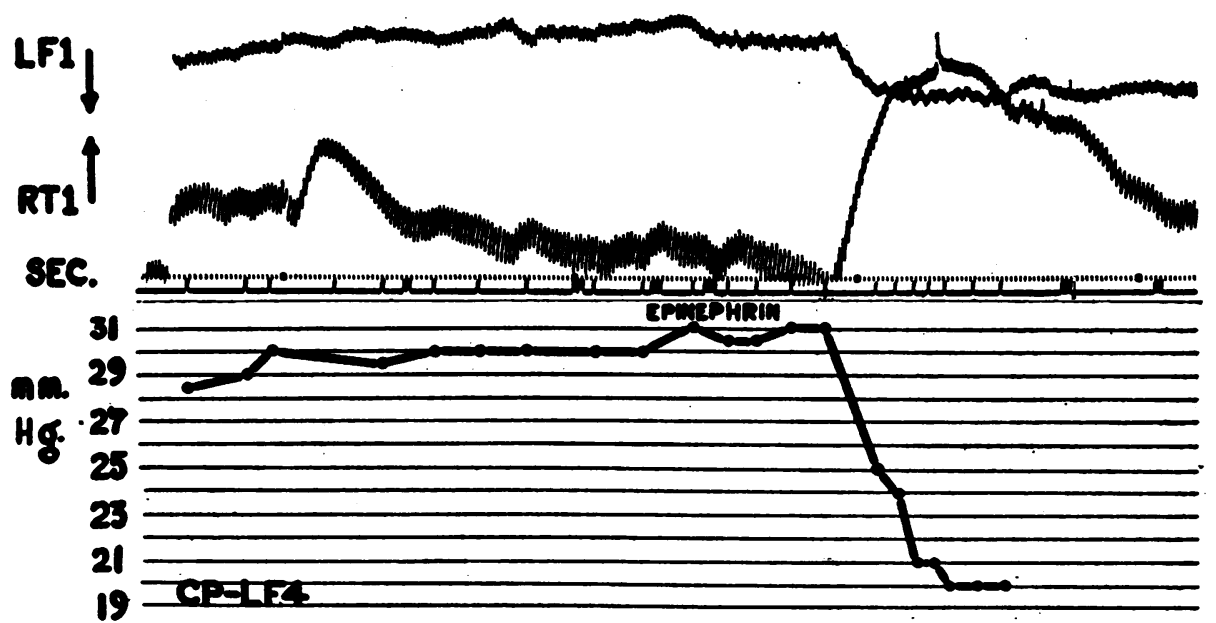

Fig. 4. Subject C. M. Raynaud's Disease with Scleroderma of Hands and Feet

A and B. Simultaneous observations of capillary blood pressure in a sympathectomized digit and of digital volume in a sympathectomized and in a normally innervated digit during vasoconstrictions induced by the intravenous injection of 1 gamma of epinephrin on two occasions. Preganglionic sympathectomy of left upper extremity. Intact innervation right lower extremity. Capillary blood pressure measured in the venous limb of the same capillary loop. Skin temperature LF3, $35.0^{\circ} \mathrm{C}$. Room temperature, $30.2^{\circ} \mathrm{C}$. Arterial pressure, left arm $112 / 72 \mathrm{~mm}$. Hg. Note absence in the sympathectomized (LF1) digit of the spontaneously occurring vasoconstrictions recorded in the digit (RT1) with intact innervation. 
after interruption of the sympathetic pathways, intravenously administered epinephrin caused reductions in both digital volume and capillary blood pressure of a degree equal to that occurring in normally innervated digits.

Because of technical difficulties, most of the foregoing observations were made on the abnormally large capillaries of patients with Raynaud's disease. General conclusions can, therefore, be reached only with reservations. However, it was reassuring to find that under the conditions imposed, neurogenic vasoconstrictions affected capillary blood pressure similarly in normal and abnormally large capillaries.

The contemplated comparison of capillary blood pressure in normal and hypertensive subjects made it desirable to find a state during which the capillary blood pressure would be relatively constant and relatively unaffected by vasoconstrictor stimuli. It was hoped that reflex vasodilatation or the local hyperemia induced by histamin would provide such a state. This proved not to be the case. Neurogenic vasoconstrictions, with resulting changes in capillary blood pressure, could be abolished only by the interruption of the sympathetic pathways. Even then, epinephrin injected intravenously continued to induce a decrease in both digital volume and capillary blood pressure. However, it is believed that during moderate digital vasodilatation the changes induced in capillary blood pressure by neurogenic vasoconstriction are not so great as to preclude comparative studies.

It is emphasized that the data here presented and the conclusions derived therefrom, apply only to the digital capillaries. The digits possess specialized vascular areas, the blood flow through which is readily affected by many factors. The capillary blood pressure in these specialized areas need not necessarily be indicative of the capillary blood pressure elsewhere in the body. Generalized conclusions based upon data derived from local vascular areas should, therefore, be viewed with reservation.

\section{SUM MARY}

1. In the normal-sized digital capillaries of healthy subjects and of hypertensive patients, neurogenic vasoconstrictor stimuli brought about decreases in capillary blood pressure of from 5 per cent to 33 per cent.
2. Reflex vasodilation in the digit, even when combined with local vasodilatation produced by histamine, failed to prevent the fall in capillary blood pressure which occurred in response to neurogenic vasoconstrictor stimuli.

3. The percentage variation in digital capillary blood pressure was considerably smaller than the percentage variation in digital blood flow which has been reported to occur during similarly induced vasoconstrictions.

4. In the abnormally large digital capillaries of patients with Raynaud's disease and scleroderma, neurogenic vasoconstrictions, and vasoconstrictions induced by the intravenous injection of epinephrin, were usually accompanied by decreases in capillary blood pressure.

5. After interruption of the sympathetic nervous pathways to the digits of patients with Raynaud's disease and scleroderma, neurogenic vasoconstrictor stimuli failed to induce in the sympathectomized digits either vasoconstriction or fall in capillary blood pressure. On the other hand, intravenously injected epinephrin continued to cause both vasoconstriction and fall in capillary blood pressures.

6. These observations have been interpreted as indicating $(a)$ that although strong physiologic vasoconstriction mediated through sympathetic nervous pathways may be accompanied by a fall in digital capillary blood pressure, the fall is relatively slight; and (b) that the digital capillary blood pressure may remain at a relatively constant level during wide fluctuations in digital blood flow.

The authors gratefully acknowledge the assistance of Dr. Harris B. Shumacker who performed both the paravertebral blocks of the cervical sympathetic nerves and the operative preganglionic sympathectomies of the upper extremity.

This investigation was conducted with the technical assistance of Miss Margot Robinson and Miss Sara B. Merritt, B.S.

\section{BIBLIOGRAPHY}

1. Wilkins, R. W., Doupe, J., and Newman, H. W., The rate of blood flow in normal fingers. Clin. Sc., 1938, 3, 403.

2. Burton, A. C., The range and variability of the blood flow in the human fingers and the vasomotor regulation of body temperature. Am. J. Physiol., 1939, 127, 437.

3. Landis, E. M., Micro-injection studies of capillary blood pressure in human skin. Heart, 1930, 15, 209. 
4. Eichna, L. W., and Bordley, J., III, Capillary blood pressure in man. Comparison of direct and indirect methods of measurement. J. Clin. Invest., 1939, 18, 695.

5. Smithwick, R. H., Modified dorsal sympathectomy for vascular spasm (Raynaud's disease) of the upper extremity. A preliminary report. Ann. Surg., 1936, 104, 339.

6. Smithwick, R. H., The value of sympathectomy in the treatment of vascular disease. New Eng. J. Med., 1937, 216, 141.

7. Stürup, G., Bolton, B., Williams, D. J., and Carmichael, E. A., Vasomotor responses in hemiplegic patients. Brain, 1935, 58, 456.

8. Bolton, B., Carmichael, E. A., and Stürup, G., Vaso- constriction following deep inspiration. J. Physiol., 1936, 86, 83.

9. Wilkins, R. W., and Eichna, L. W., Blood flow to the forearm and calf. I. Vasomotor reactions: rôle of the sympathetic nervous system. Bull. Johns Hopkins Hosp., 1941, 68, 425.

10. Fahr, G. E., and Ershler, I., Studies of factors concerned in edema formation; hydrostatic pressure in capillaries during edema formation in right heart failure. Ann. Int. Med., 1941, 15, 798.

11. Eichna, L. W., and Bordley, J., III, Capillary blood pressure in man. Direct measurements in the digits of normal and hypertensive subjects during vasoconstrictions and vasodilations variously induced. J. Clin. Invest., 1942, 21, 711. 